\title{
"We Can Challenge our Own Racial Reality by Acknowledging Ourselves as Racial Beings with a Particular and Limited Perspective on Race" (P. 148)
}

\author{
Lynne, Erin \\ Doctoral Candidate \\ University of Colorado, Denver
}

In her book, White Fragility: Why it's so hard for white people to talk about racism, Robin DiAngelo argues that racism is an inherent component of white identity. By virtue of being white, white people participate in racism on a daily basis, intentionally or unintentionally; consciously or subconsciously. As a society, we have made racism into a good/bad binary which makes it challenging for white people to acknowledge this reality. As someone who has spent the past two decades facilitating diversity training, I find that DiAngelo has incredible knowledge and experience to share on the subject. She was previously a tenured professor of multicultural education, with a focus on whiteness studies and her work is highly regarded and has had significant influence on her field. Throughout the book, she references her lived experiences as a diversity trainer which serves to both depict the issues she is referencing and give credibility on the topic.

DiAngelo relates many stories of white people engaging in conversations about race, describing their hurt feelings and need for comfort as "white fragility." She references countless examples in which white fragility, the need for white people to feel comfortable and unchallenged in conversations about racism, has led to people of color in the space feeling marginalized which has prevented any learning or growth from happening. She speaks primarily about progressive white people who seek out opportunities to grow their anti-racist practices and yet refuse to hear, see, or acknowledge their racist practices. She calls out this paradox in that white people want to end racism, but the ways in which they demand to be treated in conversations about racism simply reinforce said racism.

DiAngeloprovides a detailed history of the socialization of white people to become inherently racist. She describes the ways in which racism is interwoven in the very beings of white people because they spend their lives learning about their superiority through both formal and informal education. She says "Whiteness rests upon a foundational premise; the definition of whites as the norm or standard for human, and people of color, as a deviation from that norm... White people find it very difficult to think about whiteness as a specific state of being that could have an impact on one's life and perceptions" (p. 25). The socialization of being white has enabled white people to ignore the ways in which they benefit from institutional racism and has allowed them to disengage from the difficult conversations about how to minimize it.

In response to the very well defined challenge of white people being blind to the depths of racism and their own racist behavior,DiAngelo makes a number of recommendations. She first asks readers to move away from the good/bad binary of racism and accept the reality of its inherent presence in the very existence of white people. Once white people are able to get beyond feeling judged for their perceived racist behavior, they can begin to move forward. In the final chapter, DiAngelo provides recommendations for shifts in how white people and people of color operate to support opposing racism. She discusses the need for white people to "build racial stamina" in order to endure the emotional toll conversations about racism can have on them without putting their feelings back on people of color. She provides specific recommendations for how to respond, emotionally and physically, in a space where a white person's racism is being confronted so as not to perpetuate racism.

The recommendations Diangelo makes provide numerous examples of how white people can engage in conversations about racism, confront their own racist behavior, and learn and develop new skills to dismantle the racist systems that exists. Our predominantly white teaching force must read this book and enact the recommendations in order to drive toward equitable outcomes for all students. The format and content of the book are accessible and digestible, providing numerous stories of various ways in which "white fragility" plays out in the world around us which allows readers the opportunity to connect to various entry points into the content. Every white reader in education will find a way to connect to the content and find ways to implement the recommendations in their daily lives - both personally and professionally. People of color will also be able to connect to the stories and the content as it relays the lived experience of people of color who are consistently shut down by white people. They may well see themselves reflected in the stories that are shared and feel hopeful that the recommendations will shift the way some white people interact with them. 
The topic DiAngelo addresses in White Fragility is one that is extremely important in the current social and political climate. It is also essential in conversations about learning and education. Given her numerous examples and strong evidence from other researchers in the field, the recommendations she provides appear to be effective in helping white people engage with the topic of racism. As a teacher educator who trains predominantly white teachers who teach predominantly students of color, I believe the content in this book is essential reading for all beginning teachers, especially white ones. In my experience working with white teachers, I have seen first-hand how often their own "fragility" stands in the way of their ability to acknowledge their biases. This makes it incredibly challenging for them to build relationships with their students and therefore, extremely challenging for their students to engage in meaningful learning. Our teachers must be comfortable reflecting on their own biases and how those biases may be impacting the students with whom they work, but they will not be able to do so authentically and meaningfully if they are not comfortable being confronted by their own racism.

As educators, we must recognize that, as DiAngelo says, "the default of the current system is the reproduction of racial inequality; our institutions were designed to reproduce inequality and they do so with efficiency. Our schools are particularly effective at this task" (p. 153). Therefore, it is on all of us to do the challenging work of engaging in these conversations to create more equitable outcomes for our students of color.

\section{Reference}

DiAngelo, R.J. (2019). White fragility: why it's so hard for white people to talk about racism. Boston, MA: Beacon Press 